\title{
Implications of Covid-19 Pandemic Toward Business Contracts
}

\author{
Dikha Anugrah ${ }^{1}$, Teten Tendiyanto ${ }^{2}$, Haris Budiman ${ }^{3}$ \\ ${ }^{123}$ Faculty of Law, Universitas Kuningan, Kuningan, Indonesia \\ \{dikha@uniku.ac.id ${ }^{1}$, teten.tendiyanto@uniku.ac.id², haris.budiman@uniku.ac.id ${ }^{3}$ \}
}

\begin{abstract}
The Corona Virus Disease 2019 (Covid-19) pandemic has had a major impact on various business sectors in Indonesia, besides that the Covid-19 pandemic has implications for business contracts made by parties. The purpose of this research are to find and analyze the implications of the Covid-19 pandemic on existing business contracts. The research method used by the author is Juridical Normative, with a means of collecting data through literature study. The results of this study indicate that the occurrence of the Covid-19 pandemic can also be said to be a force majeure, which has implications for business contracts made by parties. The conclusion in this study is that the implication of the Covid-19 pandemic on business contracts is that the debtor in a business contract is not required to pay losses and costs, fines and interest due to obstruction of fulfilling obligations. The problem that may arise is if the context of the COVID-19 pandemic has not been specifically regulated, especially if it is not included in the callusula contract as a force majeure so that risk responsibility can be shared. If a pandemic is included in the clause as a force majeure, then a force majeure claim can be submitted on a case-by-case basis, and based on the consideration that the matter is filed in good faith and based on proper legal references. In addition, submission of force majeure must also be made with the intention of changing the agreement, not ending it and still having to prioritize deliberative settlement and remain subject to the dispute settlement procedures stipulated in the agreement
\end{abstract}

Keywords: Covid-19 Pandemic; Implications; Business Contracts

\section{Introduction}

At the beginning of 2020, we were busy with efforts to contain the spread of the Corona Virus Disease 2019 (Covid-19) pandemic. Since the emergence of the first case in November 2019 and then in Wuhan, China, the number of reported cases has continued to increase then gradually decreased and there have been fluctuations that have led to improvement. Until 2 August 2020, WHO released global distribution data that out of 216 countries 17,660,523 confirmed cases with a death status of 680,894 people. In Indonesia, the Covid-19 Handling Acceleration Task Force noted that up to August 19, 2020, 144,945 positive cases were recorded, with 98,657 recovered cases and 6,346 deaths.

Based on the official website of the World Health Organization (WHO), it is stated that the Coronavirus is a group of viruses that can cause disease in animals or humans. Several types of coronavirus are known to cause respiratory tract infections in humans ranging from colds to more serious coughs such as Middle East Respiratory Syndrome (MERS) and Severe Acute Respiratory Syndrome (SARS). The newly discovered coronavirus causes COVID-19. 
COVID-19, which has been designated as a national non-natural disaster through the President Permenkes Number 12 of 2020 concerning the Determination of Non-Natural Disaster for Corona Virus Disease 2019 (COVID-19) Spread as a National Disaster, requires various mitigation efforts carried out by the government, including enter the call to implement social and physical distancing following the WHO protocol that must be carried out by the community. In addition, the 2019 Corona Virus Disease (Covid-19) pandemic has had a major impact on various business sectors in Indonesia, especially having a direct impact on the hotel, transportation, tourism, manufacturing and other business sectors that depend on direct human interaction. The Social Distancing policy exposes various businesses to disturbances, especially in failure to comply with agreements or default.

Fornano \& Wolf researchers (Corona and Macroeconomic Policy, 2020), stated that "the coronavirus outbreak will cause a negative supply shock to the world economy, by forcing factories to shut down and disrupting global supply chains". The Institute for Development of Economics and Finance (INDEF) then abstracted the results of Fornano \& Wolf's research in simpler language that the COVID-19 pandemic is predicted to cause supply-demand-side shocks which include decreased production of goods - decreased income - a wave of layoffs. decreased purchasing power - decreased demand for goods.

The issuance of Presidential Decree Number 12 of 2020 is the legal basis for determining the Covid-19 Pandemic as a Non-Natural National Disaster. However, the issuance of Presidential Decree No. 12 of 2020 has not failed to cause a separate polemic regarding Civil Law Actions, particularly regarding the legitimacy of force majeure. A number of parties have said that this Presidential Decree can become a legitimation that the COVID-19 pandemic is a force majeure so that it can be used as a basis for reasons to cancel an agreement or contract. If so, then the Covid-19 pandemic can also be said to be a force majeure which is an obstacle where one party does not have the ability to avoid the obstacle even though they have made their best efforts,

One of the most felt problems by business actors as suppliers, service providers, service providers, distributors and consumers is that they will experience an unfavorable situation during the COVID-19 pandemic. For debtors, a decrease in turnover due to reduced demand will have an impact on the ability to pay credit to creditors, and can even result in default. In connection with this, OJK then issued Financial Services Authority Regulation Number $11 /$ POJK.03 / 2020 concerning National Economic Stimulus as a Countercyclical Policy on the Impact of the Spread of Corona Virus Disease 2019.

According to these regulations, Banks can provide restructuring / credit relief / financing to debtors. The condition is that the debtor is affected by the spread of Corona Virus Disease 2019 (COVID-19), either directly or indirectly, which causes the debtor to experience difficulties in fulfilling obligations to the Bank (conventional commercial banks, including sharia business units, Islamic commercial banks, people's credit banks, Islamic people's finance bank). Thus it is necessary to re-examine by the creditor that several factors that can cause bad credit apart from the pandemic are the debtor's business decline, debtor failure so that business income is reduced or the character of the debtor himself who deliberately refuses to pay his obligations.

The state of the Covid-19 pandemic which qualifies as a force majeure has implications for business contracts made by the parties. This is confirmed in Article 1244 of the Civil Code, Article 1245 of the Civil Code, Article 1444 of the Civil Code and Article 1445 of the Civil Code. Referring to several of these articles, the implication of the Covid-19 pandemic for business contracts is that the debtor in a business contract is not required to bear losses and pay fees, fines, and interest resulting from failure to fulfill obligations. In the case of the 
Covid-19 pandemic, the context of compensation for losses in epidemic conditions still has to refer to the form of the agreement first. If it has not been specifically regulated, all people involved in the transaction should bear the risk and still apply the principle of justice,

With this policy, it is hoped that it can provide convenience for the community and business actors so that running business contracts will still be valid and even though some of them may impose provisions that a pandemic is categorized as a force majeure. Submitting a force majeure claim is highly dependent on several factors including the type of agreement and the character of the perpetrator's business, thus this force majeure claim must be made on a case by case basis, and is based on the consideration that it is submitted in good faith and based on proper legal references. In addition, submission of force majeure must also be made with the intention of changing the agreement.

\section{Method}

The research method used is normative juridical, which is an approach method by studying the law which is conceptualized as a norm or rule that applies in society, and serves as a reference for everyone's behavior. data collection tool through library research. used secondary, that is data obtained through the study of documentation by reading scientific books, magazines, internet, newspapers and other readings related to research.

\section{Result and Discussion}

\subsection{Covid-19 and the Indonesian Economy}

President Joko Widodo announced that Indonesia was affected by the virus on March 2, 2020, calling it a disaster. The National Disaster Management Agency (BNPB) specifically called Covid-19 a non-natural disaster with a national coverage scale. The Covid-19 pandemic has had a huge impact on the Indonesian economy. Various international economic agencies such as the World Bank estimate that this pandemic will affect national economic growth to reach $-3.5 \%$ to $2.1 \%$ in 2020 . In addition, the IMF also predicts Indonesia's economic growth of $0.5 \%$ in 2020 which means there was a decline recorded in 2019 from a growth rate of $5.02 \%$. While from the social side which is also closely related to the country's economy, several institutions predict that there will be an additional 1.16 million $(+0.44 \%)$ to 9.6 million $(+3.6 \%)$ poor people in 2020 , and also an increase in the number of unemployed is estimated. 2.91 million ( $2.17 \%$ workforce) to 5.23 million (3.79\% workforce) in 2020 .

This uniform impact on various sectors related to the economy is basically due to the uncertain nature of the fatal risk of the Covid-19 pandemic. In addition, the news that an effective vaccine was found, which is the cause of asymmetric information, causes all social activities to be shrouded in uncertainty and have risks

\subsection{Covid-19 as Force Majeure}

An engagement is a legal relationship between two people or two parties, based on which one party has the right to demand something from the other party (the creditor), and the other party is obliged to fulfill the claim (the debtor). To realize an agreement that has been mutually agreed upon, the parties bound by the agreement can carry out the contents of the agreement accordingly. If the demands are not fulfilled voluntarily, the debtor (creditor) can 
sue them in front of a judge. Or in other words, if the debtor (debtor) does not do what he promised, then he is said to have committed "default" (broken promise).

Covid-19 has caused an economic shock, which affects the economy individually, households, micro, small, medium and large companies, and even affects the country's economy with coverage scales from local, national and even global. Generally, in an agreement made by the parties, a force majeure clause can be found. Force majeure is often translated as a coercive situation that causes a debtor to be prevented from carrying out his performance due to unforeseen circumstances or events at the time the contract was made, these circumstances or events cannot be accounted for to the debtor, while the debtor is not in a bad faith situation.

According to the Legal Dictionary, default means negligence, negligence, failure to keep promises, not fulfilling contracts. So, default is a condition in which a debtor (indebted) does not perform the performance required in a contract, which can arise because of the debtor's deliberate or negligence and the existence of a compelling situation (overmatch). Indonesian law regulates force majeure, which in the Civil Code is referred to as overmatch or coercion. Indeed, it does not explicitly explain the definition of force majeure, but the state of force is regulated in Article 1244 and Article 1245 of the Civil Code.

Article 1244 of the Civil Code:

"The debtor must be punished to cover costs, losses and interest. if he is unable to prove that the non-performance of the contract or the improper timing of carrying out the engagement was caused by something unforeseen, which cannot be borne by him. although there is no bad faith to him".

Article 1245 of the Civil Code:

"There is no reimbursement for expenses. losses and interest. if due to coercive circumstances or because of something that happens coincidentally, the debtor is prevented from giving or doing something that is required, or from committing an act that is forbidden to him. "

The provisions in the two articles stipulate that the condition of coercion is "unexpected", "the debtor is prevented from giving or doing something that is required", and "cannot be borne by him".

However, the context of the state of force does not explain its type in the Civil Code. A common practice is to describe the types of force majeure in a contract, such as events that occur beyond the control of the parties, namely floods, earthquakes, rainstorms, hurricanes (or other natural disasters), fires, power outages, wars, demonstrations, civil wars, rebellions, revolutions, military coups, terrorism, nationalization, blockades, embargoes, labor disputes, strikes, epidemics, and sanctions against a government. In terms of force majeure, in an agreement it is often referred to as an overmatch; act of god, force majeure, emergency, force majeure, circumstances beyond human ability. Force majeure in contract law is a condition in which a person who is obliged (debtor) is prevented from carrying out his / her performance due to circumstances or events that are unexpected and cannot be anticipated at the time the agreement is made that issues the obligation, and such circumstances or events cannot be legally accounted for to the debtor concerned, while the debtor is not in a bad faith situation.

Based on this, there are several opinions which state that covid-19 is included in force majeure, because it is an obstacle where one party does not have the ability to avoid the obstacle even though it has made the best efforts, and the obstacle cannot be predicted when it will occur and either party does not have a contributing factor in the occurrence of this obstacle. The determination of COVID-19 as a national disaster is stipulated in Presidential Decree (Keppres) 12/2020 concerning the Designation of Non-Natural Disaster for the Spread of Corona Virus Disease 2019 (COVID-19) as a National Disaster. 


\subsection{Implications of Covid-19 for Business Contracts}

A claim for default always starts in the existence of a contractual legal relationship (agreement) between the parties, so that it gives birth to legal rights and obligations (achievement). The legal aspect is one of the important aspects in every community and institution such as banking or other types of business, thus all legal activities need to be equipped with knowledge of law and also the ability to solve all problems. In the context of contract law, what the parties agree on will become the law that must be obeyed. If the parties do not include a force majeure clause in the agreement, they can refer to the provisions in Article 1245 of the Civil Code which complement the contents of the agreement. The debtor in this case can prove his failure to meet performance due to unexpected events. What is likely to be a problem is if the parties regulate otherwise, namely that this pandemic is not part of the force majeure. By not including the clause that the pandemic spread of the virus is one type of force majeure situation, this cannot be classified as a force majeure.

The existence of a corona virus outbreak that occurs is difficult to immediately interpret as force majeure. Not all companies have stopped operating due to this virus, and even to this day the New Normal policy has not been able to support and improve an economy that has already declined, including in the business world related to business contracts. From this explanation, it can be seen that all the provisions that have been made by the government regarding this pandemic all boil down to the national economic interests, prosperity, welfare and happiness of the entire people and legal certainty. As stated by Kelsen, legal norms must be appropriate, not only creating laws but also not contradicting a higher legal norm, namely the Basic Norm.

Things that might be different if there are decisions or policies of local and national governments whose provisions directly hinder the implementation of achievements or obligations in the contract agreement, this can be classified as a force majeure situation. The current situation is easier to classify as force majeure if it is confirmed by a regulation issued by the competent government. So that the obstruction of a party from fulfilling achievements due to the corona virus outbreak is included in a state of force majeure. Then the risks arising from it are shared by the parties to the agreement. Except in the case that the parties have regulated who bears the risk in case of force majeure.

The state of the Covid-19 pandemic, which qualifies as force majeure, has implications for business contracts made by the parties. This is confirmed in Article 1244 of the Civil Code, Article 1245 of the Civil Code, Article 1444 of the Civil Code and Article 1445 of the Civil Code. According to Black's Law Dictionary, force majeure is "an event or effect that can be neither anticipated nor controlled". In Indonesia's material civil law, the term force majeure is not strictly regulated. However, Article 1245 of the Civil Code (KUHPerdata) states that parties to an engagement are not obliged to provide compensation if the party is prevented from fulfilling its obligations due to an overmatch.

From the provisions of Article 1245 of the Civil Code and the Black's Law Dictionary, there is a common thread that the party cannot be asked for compensation in the event of a situation that cannot be predicted beforehand or is beyond reasonable control due to external factors. The provisions of Article 1245 of the Civil Code are contained in Book Three on Engagement - Chapter I on Engagement in General. This means that the provisions of Article 1245 of the Civil Code actually apply to the parties in an engagement with the condition that, first, the parties submit themselves that the civil law that applies in Indonesia is the governing law; and second, the parties do not specifically regulate the force majeure clause in the engagement. 
Referring to several of these articles, the implication of the Covid-19 pandemic for business contracts is that the debtor in a business contract is not required to bear losses and pay fees, fines, and interest resulting from failure to fulfill obligations. In the case of the Covid-19 pandemic, the context of compensation for losses in epidemic conditions still has to refer to the form of the agreement first. If it has not been specifically regulated, all people involved in the transaction should bear the risk and still apply the principle of justice, unless the agreement has stipulated who should be at risk in a pandemic condition. This also relates to consumer protection even though it is in Law no. 8 of 1999 concerning Consumer Protection has regulated the prohibition of business actors from including standard clauses in every document and / agreement regarding the transfer of responsibility, however there is still a standard clause which contains exceptions. Therefore, legal protection is also needed for parties who are in a weak bargaining position so that they do not fall under compulsion to accept the agreement in a bargaining position. The pandemic clause as a force majeure can also be used as legal protection which does play a role in protecting common interests.

Based on the theory, there are 2 (two) types of force majeure, namely absolute force majeure and relative force majeure. Absolute force majeure occurs when the obligation really cannot be carried out completely, for example when objects are destroyed due to natural disasters. In this case, it is impossible to fulfill the achievement by anyone or everyone. Meanwhile, relative force majeure occurs when an agreement is still possible to implement but at a very large sacrifice or expense from the debtor. Furthermore, due to force majeure, there are 2 (two) possibilities, namely Termination of Agreement or Suspension of Liability. Termination of the agreement occurs when the obstacle is permanent. Meanwhile, postponement of obligations occurs when a force majeure event is temporary. When the obstacle condition has recovered, for example, the export ban is lifted again, then the obligation of the seller will recover to hand over the exported goods.

In this regard, based on the doctrine, various kinds of force majeure conditions have been mentioned, which can be categorized as follows:

a. Objective force majeure and subjective force majeure

b. Absolute force majeure and relative force majeure

c. Permanent force majeure and temporary force majeure

d. Force majeure for agreements in general and force majeure for certain agreements only.

e. Force majeure because of the impossibility, impracticability and frustration of the intent of the agreement.

The Covid 19 outbreak can be categorized as a reason for subjective force majeure, in which this situation is a compelling situation so that the achievement of an agreement cannot be fulfilled due to matters related to the actions or abilities of the debtor itself, without any elements. error and without an element of good faith from the debtor concerned. In another sense, for example, someone is tested positive for the Covid 19 Virus or someone is being monitored, then this is considered the debtor as unable to excel at that time. Submitting a force majeure claim depends on several factors, including the type of agreement and the character of the business of the actor. Therefore, the force majeure implementation claims from one case to another may be different (case by case basis). There are several considerations in filing a force majeure claim, including:

a. Force majeure claims are submitted in good faith and in accordance with the notification procedures agreed in the agreement. The parties to an engagement need to understand that the principle of good faith does not only apply at the time of implementation of the agreement, but since the preparation of the agreement (pre-contract), implementation of the agreement (during the period of contract), and dispute settlement (disputes 
settlement). Even though it is factually affected by the COVID-19 pandemic, parties who claim force majeure must be based on good faith and always try to do things that are deemed appropriate and reasonable to carry out their obligations.

b. Claim force majeure is based on precise legal references. The party submitting the claim must first examine whether a disaster, pandemic or government action applies certain rules including the scope of force majeure accommodated in the agreement. If, the force majeure claim is based on the existence of government action, the claimant is encouraged to prove that the government's action has a real impact on their business activities / activities. The claimant must be able to properly prove that the existence of force majeure has an impact on the fulfillment of obligations and the legal basis in accordance with the context of the legal relationship between the parties.

c. Claims are submitted with the intention of changing the agreement and not ending the agreement. Claims of force majeure do not automatically invalidate the party's obligations. The provisions of Article 1245 of the Civil Code even state that claims of force majeure are related to the exemption of the obligation to compensate for losses. Therefore, at the time of filing a force majeure claim, the party should have prepared alternative changes to the agreement, for example in the form of a change in deadline for credit / financing payments, or other alternatives.

d. Claims are submitted while still prioritizing deliberative settlement and still subject to the dispute resolution procedures stipulated in the agreement.

e. Parties related to business contracts and who wish to state that the Covid-19 pandemic is a force majeure must consult a practitioner or legal consultant regarding legal options that can be made.

With this policy, it is hoped that it can provide convenience for the community and business actors so that running business contracts will still be valid and even though some of them may impose provisions that a pandemic is categorized as a force majeure. Submitting a force majeure claim is highly dependent on several factors including the type of agreement and the character of the perpetrator's business, thus this force majeure claim must be made on a case by case basis, and is based on the consideration that it is submitted in good faith and based on proper legal references. In addition, submission of force majeure must also be made with the intention of changing the agreement.

\section{Conclusion}

The implication of the Covid-19 pandemic for business contracts is that debtors in business contracts are not required to bear losses and pay fees, fines, and interest resulting from failure to fulfill obligations. The problem that may arise is if the context of the Covid-19 pandemic has not been specifically regulated, especially if it is not included in the callusula contract as a force majeure so that risk responsibility can be shared. If a pandemic is included in the clause as a force majeure, then a force majeure claim can be submitted on a case by case basis, and based on the consideration that it was filed in good faith and based on proper legal references. In addition, submission of force majeure must also be made with the intention of changing the agreement. 


\section{References}

[1] Asser, 1991, Pengajian Hukum Perdata Belanda, Page. 368-369

[2] Indonesia, 2020, Program Pemulihan Ekonomi Nasional (PEN), April 2020.

[3] Mariam Daruz Badrulzaman. 1996, KUHPerdata Buku III: Hukum Perikatan dengan Penjelasan.

[4] Muhammad Syaifudin, 2012, Hukum Kontrak Memahami Kontrak Dalam Perspektif Filsafat, Teori, Dogmatik, dan Praktik Hukum (Segi Pengayaan Hukum Perikatan), CV Mandar Maju, Bandung.

[5] Munir Fuady, 2016, Konsep Hukum Perdata, Raja Grafindo Persada, Jakarta.

[6] Putra PM Siregar \& Ajeng Hanifa Zahra, Bencana Nasional Penyebaran COVID-19 sebagai Alasan Forece Majeure, Apakah Bisa?, in https://www.djkn.kemenkeu.go.id/artikel/baca/13037/BencanaNasional-Penyebaran- COVID-19 as-Reason-Force-Majeure-Can-Can.html, accessed on 10 August 2020 at $15.00 \mathrm{WIB}$

[7] Subekti, 2002, Hukum Perjanjian, PT. Intermasa, Jakarta.

[8] Who.int, Questions and answers related to Coronavirus, in https://www.who.int/indonesia/news/novel-coronavirus/qa-for-public, accessed on 10 August 2020 at 15.00 WIB.

[9] Putri Maha Dewi, Credit Insurance as an Effort to Overcome Bad Credit Risk in Modern Banking Economy in the Industrial Revolution 4.0 in Indonesia. UNIFIKASI: Jurnal Ilmu Hukum Vol. 07 No. 01,2020 , p. 88

[10] Suwari Akhmaddhian and Asri Agustiwi, Perlindungan Hukum Terhadap Konsumen dalam Transaksi Jual Beli secara Elektronik di Indonesia, UNIFIKASI: Jurnal Ilmu Hukum, Vol. 03 No. 02, 2016. p. 40

[11] Lukmanul Hakin, Credit Banking in Business Law Perspective, UNIFIKASI: Jurnal Ilmu Hukum, Vol. 6 No. 01, 2019. Pg. 53

[12] Gios Adhiyaksa. "Penerapan Asas Perlindungan Yang Seimbang Menurut Kuhperdata Dalam Pelaksanaan Perjanjian Kerja Untuk Waktu Tertentu Dihubungkan Dengan Undang-Undang Nomor 13 Tahun 2003 Tentang Ketenagakerjaan”. UNIFIKASI: Jurnal Ilmu Hukum. 3 (2). 2016. 77-87

[13] Dian Alan Setiawan, The Implication of Pancasila Values on the Renewal Law in Indonesia, UNIFIKASI: Jurnal Ilmu Hukum, vol. 05 No 02, 2018, p. 63

[14] Fradhana Putra Disantara, The Validity of Rector's Circular Letter on the Covid-19 Pancemic, UNIFIKASI: Jurnal Ilmu Hukum, Vol. 07 No. 1, 2020. Pg 126

[15] Agus Surachman, Criticism of Law no. 25 of 2007 concerning Investments (Legal Theory Perspective), Journal of Law UNFIKASI Vol. 05 No. 01, 2018, p. 24 